\title{
Bla g 1 ALLERGEN LEVELS IN ZAGREB AREA HOUSEHOLD DUST
}

\author{
Ljerka PRESTER and Jelena MACAN \\ Institute for Medical Research and Occupational Health, Zagreb, Croatia \\ Received in October 2010 \\ CrossChecked in October 2010 \\ Accepted in January 2011
}

\begin{abstract}
Cockroach allergy is a health problem in many parts of the world. In urban environments, indoor exposure to cockroach allergens involves a risk of asthma. The aim of this study was to measure the mass fraction of Bla g 1, a major allergen of the German cockroach (Blatella germanica) in 30 house samples, collected at random from Zagreb area households, Croatia. Dust samples were collected on cellulose filters by vacuuming living rooms floors. After extraction, Bla g 1 was detected using the commercial enzyme-linked immunosorbent assay (ELISA). Only four of the thirty households had detectable Bla g 1 levels, and only in one was its concentration higher than $2.0 \mathrm{U} \mathrm{g}^{-1}$, the threshold associated with sensitisation. The Bla $\mathrm{g} 1$ ELISA proved highly sensitive, with the detection limit of $0.12 \mathrm{U} \mathrm{g}^{-1}$. The within- and between-assay imprecision was $8.9 \%$ and $14.4 \%$, respectively, and accuracy $85 \%$ to $120 \%$. Low Bla g 1 levels in the household dust support previously reported low prevalence of skin sensitisation to B. germanica among Zagreb residents. Further monitoring should reveal if there are differences in cockroach allergen exposure and sensitisation between households from other geographic areas in Croatia.
\end{abstract}

KEY WORDS: allergy, cockroaches, ELISA, indoor allergens

The prevalence of allergic airway diseases such as asthma has been increasing in many countries worldwide including Croatia $(1,2)$. Indoor allergens from dust mites, pet dander, moulds, and cockroaches pose an important risk of developing chronic respiratory diseases (3). Cockroach infestation and the resulting allergen exposure are associated with the development of asthma in genetically predisposed children (4). Several authors have confirmed this interaction between environmental and genetic factors in the aetiology of cockroach allergen-related asthma (3-6). The most common household cockroach species are Blatella germanica (German cockroach) and Periplaneta americana (American cockroach). While B. germanica is common in the northern hemisphere, especially in the United States and Europe, $P$. americana is predominant in tropical countries such as Taiwan and Brazil, especially in food related areas
(7). B. germanica contains multiple allergens (Bla g 1, Bla g Bd90K, Bla g 2, Bla g 4, Bla g 5, Bla g 6, Bla g 7), of which Bla g 1 and Blag 2 have been produced for immunoassays (7-9). Bla g 1 belongs to cross-reacting group 1 allergens $(10,11)$.

Cockroach infestation leads to accumulation of allergens in reservoir household dust (particles $>10$ $\mu \mathrm{m}$ in diameter) $(7,12,13)$. Cockroach allergens have been located all over the insect, especially in the saliva, gut, faeces, cast skins, and all over their dead bodies $(8,12)$. Similar to mites, sensitisation to cockroach allergens is dose-dependent $(14,15)$. Generally, allergen content in settled dust is a good proxy for inhalant exposure $(1,3)$. Concentrations of cockroach allergens that actually lead to sensitisation and to symptoms are not well-defined. Several authors have proposed that Bla $\mathrm{g} 1$ level greater than $2 \mathrm{U} \mathrm{g}^{-1}$ of settled dust is associated with sensitisation in 
susceptible individuals, whereas exposure to $8 \mathrm{U} \mathrm{g}^{-1}$ is associated with symptomatic asthma $(1,3,7,14)$. However, in susceptible individuals, especially in children, cockroach allergens inhaled as aerosols may induce IgE-mediated hypersensitivity at levels below currently proposed thresholds $(14,16-18)$.

In general, cockroach infestation and the resulting allergen exposures are common in both urban and rural homes in the United States (16, 18-20). Exposure to cockroach allergens is associated with asthma morbidity, especially in children (19-22) and the elderly (23) living in low-income households. A similar pattern has been observed in some Asian countries $(24,25)$. However, there are relatively little data about indoor exposure to cockroach allergens in European countries, and Bla g 1 has not yet been measured in Croatia.

The capture enzyme-linked immunosorbent assay (ELISA) has widely been used as a standard test in epidemiologic studies for indoor allergen assessment including cockroach allergens and for monitoring the effectiveness of allergen-avoidance measures (26-29). The aim of this pilot study was to determine Bla $\mathrm{g} 1$ levels in middle-class households in the Zagreb area using the Bla g 1 ELISA.

\section{MATERIALS AND METHODS}

\section{Dust collection and extraction}

Thirty dust samples were collected from 30 randomly selected homes in a wider Zagreb city area during 2007 as part of a research project involving residential and occupational exposure to dust allergens. Dust settled on living-room floors was collected on cellulose filters (Heska AG, Freiburg, Switzerland) with an adapted hand-held vacuum cleaner following a standard protocol (30). There were no visual signs of cockroach infestation, and no visible signs of humidity. All samples were stored at $-20^{\circ} \mathrm{C}$ and extracted within a period of month. Before extraction, the samples were manually sieved (pore diameter 400 $\mu \mathrm{m})$ to remove large nondust debris and then weighted. One hundred-milligram aliquots of fine dust were extracted with $2 \mathrm{~mL}$ of phosphate-buffer saline containing $0.05 \%$ Tween (PBS-T), shaken with a wrist-action shaker (Ika, Vortex, Germany) and left at room temperature for $2 \mathrm{~h}$. Dust extracts were centrifuged at $1800 \mathrm{~g}$ for $10 \mathrm{~min}$ and supernatants stored in plastic tubes at $-20{ }^{\circ} \mathrm{C}$ until assayed for Bla g 1 content.

\section{Protocol of Bla g 1 ELISA protocol}

Standard, capture (purified mouse anti-Bla g 1 $\mathrm{mAb}$, isotype IgG1, product code: MA-10A6), and secondary (rabbit anti- $B$. germanica pAb, product code: PA-BG1-1) antibodies were purchased from Indoor Biotechnologies Ltd. (Cardiff, UK). Purified $B$. germanica allergen extract was used as reference standard (10 U mL-1 Bla g 1, product code: ST-BG 1). The detecting antibody (goat anti-rabbit $\operatorname{IgG}$ ) was conjugated to horseradish peroxidase (Jackson Immunoresearch Laboratories, Inc., West Grove, PA). Assay buffer containing $1 \%$ bovine serum albumin (BSA) (Sigma, USA, lot no.017K0775) (PBS-T-BSA) was used to achieve the desired dilution of extracts, standards, and antibodies. A 7-points calibration curve $\left[(0,0.004,0.008,0.016,0.032,0.063,0.125) \mathrm{U} \mathrm{mL}^{-1}\right]$ was made on every plate. Dust extracts were diluted 5 to 10 times using PBS-T-BSA.

Bla g 1 levels were determined as described elsewhere $(10,29,30)$. Maxisorp 96-well microtiter plates (NUNC, Roskilde, Denmark) were coated with $100 \mu \mathrm{L}$ per well of mAb clone 10A6 (dilution: 1/1000 in carbonate/bicarbonate buffer, $\mathrm{pH}$ 9.6) overnight at room temperature. After washing the microplate (3x300 $\mu \mathrm{L}$ PBS-T) using an automatic plate washing device, capture antibody was blocked for $30 \mathrm{~min}$ with $300 \mu \mathrm{L}$ PBS-T-BSA. Plates were washed again, and incubated with blanks, diluted extracts, standards, and controls ( $100 \mu \mathrm{L}$ per well) at room temperature for $1 \mathrm{~h}$. After washing three times with PBS, the plates were incubated with rabbit anti- $B$. germanica polyclonal antiserum (100 $\mu \mathrm{L}$ per well; dilution: $1 / 1000$ in assay buffer) for $1 \mathrm{~h}$. The plates were then washed and $100 \mu \mathrm{L}$ per well of peroxidase-labelled goat anti-rabbit IgG (dilution: 1/1000 in assay buffer) was added. After additional 1-h incubation, the plates were washed again and $100 \mu \mathrm{L}$ of substrate TMB (tetramethylbenzidine and peroxide in buffer) (Adaltis, Italy) was added to each well. Colour was allowed to develop for 10 to $15 \mathrm{~min}$, and the reaction was stopped using $100 \mu \mathrm{L}$ per well of sulphuric acid $\left(1 \mathrm{~mol} \mathrm{~L}^{-1}\right)$. Absorbance was measured at $450 \mathrm{~nm}$ using a IASON microplate reader (Graz, Austria), and unknown sample concentrations were determined by linear regression analysis of the calibration curve. Negative and positive controls were also included in each run. To exclude non-specific binding, a control plate was coated with unrelated mouse mAb (IgG1) and processed simultaneously with and under the same conditions as samples through all the steps of the analytical procedure. The absorbance values of this 
plate were subtracted from the absorbance values obtained for each individual dust extract. All analyses were carried out in duplicate and expressed as $\mathrm{U} \mathrm{g}^{-1}$ of sieved dust.

\section{Bla g 1 ELISA validation}

The limit of detection (LOD) was calculated by measuring the absorbance of 10 replicates of Bla $g$ 1free dust extract (zero dose calibrator) +3 standard deviations (matrix effect). Within-assay imprecision was established after 10 measurements of dust extracts with a medium Bla $\mathrm{g} 1$ concentration $\left(1.05 \mathrm{U} \mathrm{g}^{-1}\right)$ and expressed as coefficient of variation $(\mathrm{CV} ; \%)$. Between-assay precision was determined by measuring the concentration of the same dust extract in triplicate over three days and is expressed in percentage as $\mathrm{CV}$ between daily means. The accuracy (\%) of the method was determined by testing recovery of the same dust extract spiked with Blag 1 (1.05 $\mathrm{U} \mathrm{g}^{-1}$ of dust) in duplicate over three days.

\section{Statistics}

All data were analysed using Statistica for Windows (StatSoft, Inc 2009, USA, version 9.0). The results are presented as median and range.

\section{RESULTS AND DISCUSSION}

Table 1 shows the median and the range of Bla $\mathrm{g} 1$ in living-room dust samples and their distribution by the following categories: 1) below LOD; 2) below sensitisation threshold (0.12 to 2) $\mathrm{U} \mathrm{g}^{-1}$; and 3 ) above sensitisation threshold $\left(\geq 2.01 \mathrm{U} \mathrm{g}^{-1}\right)$. Most samples had Bla $\mathrm{g} 1$ below LOD, while only four had detectable Bla g 1 levels. A similar frequency (14\%) of Bla g 2 allergen has been reported in urban homes in Germany (31). Cohn et al. (1) reported that nearly $44 \%$ of living-room dust samples in the US had detectable Bla g 1 levels. The highest Bla g 1 levels were observed in urban, multi-family households with low socioeconomic status (SES) and in homes built before 1940. Recent studies have highlighted high levels of cockroach allergens in homes of asthmatic residents, especially children $(14-22,32,33)$. In a Polish study (32), cockroach allergen Bla g 2 was found in $55 \%$ of house dust samples taken from homes of children with asthma. Even higher exposure to cockroach allergens has been reported in similar studies in the USA. In the National Inner City Asthma Study
Table 1 Blag 1 median mass fraction, range and level distribution in floor dust samples of 30 households in Zagreb area, Croatia

\begin{tabular}{lcc}
\hline Bla $\mathbf{~} \mathbf{1} / \mathbf{U ~ g ~}^{-1}$ & $\mathbf{N}$ & $\mathbf{\%}$ \\
\hline Median $=0.74$ & & \\
\hline Range $=0.19$ to 2.11 & & \\
\hline$<$ LOD & 26 & 86.7 \\
\hline 0.12 to 2.0 (below sensitisation threshold) & 3 & 10.0 \\
\hline$\geq 2.01$ (above sensitisation threshold) & 1 & 3.3 \\
\hline$N=$ number of positive samples & &
\end{tabular}

(NCICAS, 15), Bla g 1 was detected in $85 \%$ of bedroom dust samples taken from households in large metropolitan areas which belonged to families with asthmatic children and low SES. A similar high distribution of samples with cockroach allergens $(60 \%)$ was reported for the homes of asthmatic residents of a wide spectrum of SES in the Boston metropolitan area (33). However, in the Childhood Asthma Management Program study, which included children from eight North American cities, household Bla g 1 exposure varied considerably across cities (21). The impact of socio-demographic factors on indoor cockroach allergen exposure has been discussed in detail elsewhere $(1,18,20,33-35)$. Our median Bla $\mathrm{g} 1$ level $\left(0.74 \mathrm{U} \mathrm{g}^{-1}\right)$ is similar to $0.927 \mathrm{U} \mathrm{g}^{-1}$ found by Cohn et al. (1) in US homes ( $\mathrm{n}=831)$ (1). However, Diette et al. (5) found median Bla g 1 as high as $3.5 \mathrm{U} \mathrm{g}^{-1}$ in homes belonging to asthmatic and non-asthmatic children (overall poor, Afro-Americans or Hispanics), who resided in the metropolitan area of Baltimore. In the NCICAS study (15), even higher Bla $g$ levels (median $8.2 \mathrm{U} \mathrm{g}^{-1}$ ) were found in bedrooms of inner-city children with asthma.

However, the primary site of cockroach allergen accumulation is the kitchen $(1,10,12,16,20,36)$ and kitchen cockroach allergen levels may be considerably higher than bedroom or living room levels.

Table 1 shows that in only one sample, in our study, Bla g 1 exceeded the lower threshold of $2 \mathrm{U} \mathrm{g}^{-1}$, associated with sensitisation of atopic patients and no sample exceeded the threshold of $8 \mathrm{U} \mathrm{g}^{-1}$ associated with asthma morbidity (7). In contrast, the prevalence of samples with Bla g 1 above these threshold was considerably higher in the study of US homes by Cohn et al. (11\% above $2 \mathrm{U} \mathrm{g}^{-1}$ and $3 \%$ above $8 \mathrm{U} \mathrm{g}^{-1}$ ) (1). In a study by Wang et al. (35), the prevalence of samples with Bla g 1 levels above these thresholds was about five times higher in low-income households than in average US homes. In homes of asthma patients, the prevalence of cockroach allergens above 
Table 2 ELISA precision and limit of detectiion (LOD) for indoor allergens in Croatia reported earlier and in this study

\begin{tabular}{|c|c|c|c|c|c|c|c|}
\hline \multirow[b]{2}{*}{ Allergen } & \multirow[b]{2}{*}{$\begin{array}{c}\text { Sample } \\
\text { (floor dust) }\end{array}$} & \multirow[b]{2}{*}{$\begin{array}{c}\text { Capture } \\
\text { mAb }\end{array}$} & \multirow{2}{*}{$\begin{array}{c}\text { Secondary } \\
\text { Ab }\end{array}$} & \multicolumn{2}{|c|}{ Precision / \% } & \multirow[b]{2}{*}{ LOD } & \multirow[b]{2}{*}{ Ref. } \\
\hline & & & & $\begin{array}{l}\text { within- } \\
\text { assay }\end{array}$ & $\begin{array}{l}\text { between- } \\
\text { assay }\end{array}$ & & \\
\hline \multicolumn{8}{|l|}{ Mite } \\
\hline Der $\mathrm{p} 1$ & Houses & $5 \mathrm{H} 8$ & $4 \mathrm{C} 1$ & 6.9 & 13.1 & $0.1 \mu \mathrm{g} \mathrm{g}^{-1}$ & 38 \\
\hline Der f 1 & Houses & $6 \mathrm{~A} 8$ & $4 \mathrm{C} 1$ & 4.6 & 12 & $0.1 \mu \mathrm{g} \mathrm{g}^{-1}$ & 38 \\
\hline \multicolumn{8}{|l|}{ Moulds } \\
\hline Alt a 1 & Poultry farms & $121 \mathrm{G}$ & $121 \mathrm{G}$ & 5.3 & 12.2 & $0.12 \mu \mathrm{g} \mathrm{g}^{-1}$ & 43 \\
\hline Asp f 1 & Poultry farms & $4 \mathrm{~A} 6$ & *Ra $\alpha$ Aspf1 & 6.7 & 10.5 & $3.6 \mathrm{ng} \mathrm{g}^{-1}$ & 44 \\
\hline \multicolumn{8}{|c|}{ Cockroach } \\
\hline Bla g 1 & Houses & $10 \mathrm{~A} 6$ & *Ra aBlag1 & 8.9 & 14.4 & $0.12 \mathrm{U} \mathrm{g}^{-1}$ & $\begin{array}{c}\text { this } \\
\text { work }\end{array}$ \\
\hline
\end{tabular}

*polyclonal antibody

these limits varies widely between studies, but is usually high $(15,16,18,19,32,33)$.

Our findings of Bla g 1 levels in reservoir dust taken from homes in Zagreb area are consistent with German findings (31). In our previous study, Bla g 2 was not detected in any of 94 house dust samples determined by semi-quantitative method Dustscreen ${ }^{\mathrm{TM}}$ (Heska AG, Switzerland). Furthermore, the positive skin prick test to German cockroach allergens among adults in inland Croatia was $9.6 \%$, and $12.2 \%$ in atopic individuals, and was strongly related to skin reactivity to dust mites, probably due to the crossreactivity (37). There were no atopic monosensitised subjects to cockroach allergens in inland Croatia. Our present and earlier data do show exposure to low levels of cockroach allergens typical for well-kept households, according to Leaderer et al. (18). Moreover, these authors suggest that cockroach allergens have opposite associations with SES and population density from mite allergens; well-kept households tend to have low cockroach and high mite allergen levels. This is supported by our earlier findings (38) in the exact same samples; mite allergen Der $\mathrm{p} 1$ and Der $\mathrm{f} 1$ levels were much higher than cockroach Bla g 1 levels. A similar distribution has been reported in Germany (31), Poland (32), and in some more heterogeneous US studies $(18,21)$.

To our knowledge, there are relatively little data about the extent of cockroach allergen exposure in other European countries. A study in France (39) found very high cockroach allergen levels in low-cost public apartments, similarly to low-income homes in the US $(1,15)$. In some susceptible children, Bla g 1 levels below currently proposed thresholds may cause symptoms and contribute to asthma (16-18). Except in homes, detectable cockroach allergen levels were reported in some public places such as schools in Baltimore (median Bla g $1=2.6 \mathrm{U} \mathrm{g}^{-1}$ ) (36) and in Manchester (UK) (geometric mean Bla g 2=2.4 $\mathrm{U} \mathrm{g}^{-1}$ ) (40). These data suggest that exposure to cockroach allergens in school environment may constitute an important occupational and environmental risk of sensitisation. Not only do cockroaches carry very potent allergens, but they also vector some pathogenic bacteria, fungi, and parasites and may disseminate various infectious diseases $(8,41)$.

Monitoring of indoor allergen levels requires a very sensitive method such as ELISA. The sensitivity and precision of this method are shown in Table 2, including earlier reports for other allergens $(38,43$, 44). Its LOD of $0.12 \mathrm{U} \mathrm{g}^{-1}$ for Bla $\mathrm{g} 1$ is comparable to assay sensitivity of $0.05 \mathrm{U} \mathrm{g}^{-1}$ to $1 \mathrm{U} \mathrm{g}^{-1}$ reported previously $(1,14,16-21)$. The within- and betweenassay imprecision was $8.9 \%$ and $14.4 \%$, respectively, and accuracy $85 \%$ to $120 \%$. Thanks to the high sensitivity of the assay, dust extracts could be highly diluted in order to eliminate matrix effects.

Most of the cockroach allergens identified to date are species-specific, including Bla g $2(7,42)$. Sensitisation and exposure data suggest that Bla g 2 induces strong $\operatorname{IgE}$ response at exposure levels that are often 10 to 100 times lower than levels of other common indoor allergens $(9,13,42)$. However, group 1 allergens (Bla g 1 and Per a 1 produced by $B$. germanica and $P$. americana, respectively) share homology in their structure and significant crossreactivity $(7,8,11,12)$. Therefore, Bla g 1 ELISA may not be highly specific, and Bla $\mathrm{g} 2$ ELISA may provide a better assessment of exposure to cockroach allergens. 
Our discussion is limited to measurements of the living-room floor, and does not take into account other conditions that may have influenced allergen exposure such as urbanisation level, dwelling type, number of residents, or air conditioning. Still, our results clearly show that exposure of Zagreb area residents to cockroach allergen Bla g 1 is very low. Further epidemiological studies could look deeper into exposure to different cockroach allergens, involving a more representative sample that would include different parts of Croatia.

\section{Acknowledgement}

This study was supported by the Ministry of Science, Education and Sports of the Republic of Croatia (grant no. 022-0222411-2410).

\section{REFERENCES}

1. Cohn RD, Arbes SJ Jr, Jaramillo R, Reid LH, Zeldin DC. National prevalence and exposure risk for cockroach allergen in U.S. Households. Environ Health Perspect 2006;11: 522-6.

2. Macan J, Varnai VM, Maloča I, Kanceljak-Macan B. Increasing trend in atopy markers prevalence in a Croatian adult population between 1985-1999. Clin Exp Allergy 2007;37:1756-63.

3. Gold DR. Environmental tobacco smoke, indoor allergens, and childhood asthma. Environ Health Perspect 2000;108(Suppl 4):643-51.

4. Litonjua AA, Carey VJ, Burge HA, Weiss ST, Gold DR Exposure to cockroach allergen in the home is associated with incident doctor-diagnosed asthma and recurrent wheezing. J Allergy Clin Immunol 2001;107:41-7.

5. Diette GB, Hansel NN, Buckley TJ, Curtin-Brosnan J, Eggleston PA, Matsui EC, McCormack MC, Williams AL, Breysse PN. Home indoor pollutant exposure among innercity children with and without asthma. Environ Health Perspect 2007;115:1665-9.

6. Leung R, Ho P, Lam CWK, Lai CKW. Sensitization to inhaled allergens as a risk factor for asthma and allergic diseases in Chinese population. J Allergy Clin Immunol 1997;99: 594-9.

7. Arruda LK, Vailes LD, Ferriani VPL, Santos ABR, Pomés A, Chapman MD. Cockroach allergens and asthma. J Allergy Clin Imminol 2001;107:419-28.

8. Wu CH, Lee MF. Molecular characteristics of cockroach allergens. Cel Mol Immunol 2005;2:177-80.

9. Satinover SM, Reefer AJ, Pomes A, Chapman MD, PlattsMills TAE, Woodfolk JA. Specific IgE and IgG antibodybinding patterns to recombinate cockroach allergens. J Allergy Clin Immunol 2005;115:803-9.

10. Pollart SM, Mullins DE, Vailes LD, Hayden ML, Platts-Mills TAE, Sutherland WM, Chapman MD. Identification, quantitation, and purification of cockroach allergens using monoclonal antibodies. J Allergy Clin Immunol 1991;87: $511-21$.
11. Melén E, Pomés A, Vailes LD, Arruda LK, Chapman MD. Molecular cloning of Per a 1 and definition of the crossreactive Group 1 cockroach allergens. J Allergy Clin Immunol 1999;103:859-64.

12. De Lucca SD, Taylor DJM, O'Meara TJ, Jones AS, Tovey ER. Measurement and characterization of cockroach allergens detected during normal domestic activity. J Allergy Clin Immunol 1999;104:672-80.

13. Li M, Gustchina A, Alexandratos J, Wlodawer A, Wünschmann S, Kepley CL, Chapman MD, Pomés A. Crystan structure of a dimerized cockroach allergen Bla g 2 complexed with a monoclonal antibody. J Biol Chem 2008;283:22806-14.

14. Eggleston PA, Rosenstreich D, Lynn H, Gergen P, Baker D, Kattan M, Mortimer KM, Mitchell H, Ownby D, Slavin R, Malveaux F. Relationship of indoor allergen exposure to skin test sensitivity in inner-city children with asthma. J Allergy Clin Immunol 1998;102:563-70.

15. Rosenstreich DL, Egglestone P, Kattan M, Baker D, Slavin RG, Gergen P, Mitchell H, McNiff-Mortimer K, Lynn H, Ownby D, Malveaux F. The role of cockroach allergy and exposure to cockroach allergen in causing morbidity among inner-city children with asthma. N Engl J Med 1997;336: 1356-63.

16. Matsui EC, Wood RA, Rand C, Kanchanaraksa S, Swartz L, Curtin-Brosnan J, Eggleston PA. Cockroach allergen exposure and sensitization in suburban middle-class children with asthma. J Allergy Clin Immunol 2003;112:87-92.

17. Sporik R, Squillace SP, Ingram JM, Rakes G, Honsinger RW, Platts-Mills TAE. Mite, cat, and cockroach exposure, allergen sensitization, and asthma in children: a case-control study of three schools. Thorax 1999;54:675-80.

18. Leaderer BP, Belanger K, Triche E, Holford T, Gold DR, Kim Y, Jankun T, Ren P, McSharry J, Platts-Mills TAE, Chapman MD, Bracken MB. Dust mite, cockroach, cat, and dog allergen concentrations in homes of asthmatic children in the northeastern United States: impact of socioeconomic factors and population density. Environ Health Perspect 2002;110:419-25

19. Gruchalla RS, Pongracic J, Plaut M, Evans R, Visness CM, Walter M, Crain EF, Kattan M, Morgan WJ, Steinbach S, Stout J, Malindzak G, Smartt E, Mitchell H. Inner city asthma study: Relationships among sensitivity, allergen exposure, and asthma morbidity. J Allergy Clin Immunol 2005;115: 478-85.

20. Peters JL, Levy JI, Rogers CA, Burge HA, Spengler JD. Determinants of allergen concentrations in apartments of asthmatic children living in public housing. J Urban Health 2007;84:185-97.

21. Huss K, Adkinson FN, Eggleston PA, Dawson C, Van Natta ML, Hamilton RG. House dust mite and cockroach exposure are strong risk factors for positive allergy skin test responses in the childhood asthma management program. J Allergy Clin Immunol 2001;107:48-54.

22. Call RS, Smith TF, Morris E, Chapman MD, Platt-Mills TAE. Risk factors for asthma in inner city children. J Pediatr 1992;121:862-6.

23. Rogers L, Cassino C, Berger KI, Goldring RM, Norman RG, Klugh T, Reibman J. Asthma in the elderly: cockroach sensitization and severity of airway obstruction in elderly nonsmokers. Chest 2002;122:1580-86.

24. Lan JL, Lee DT, Wu CH, Chang CP, Yeh CL. Cockroach hypersensitivity: preliminary study of allergic cockroach asthma in Taiwan. J Allergy Clin Immunol 1988;82:736-40. 
25. Tandon N, Maitra SB, Saha GK, Modak A, Hati AK. Role of cockroaches in allergy to house dust in Calcutta, India. Ann Allergy 1990;64:155-7.

26. Gergen PJ, Mortimer KM, Eggleston PA, Rosenstreich D, Mitchell H, Ownby D, Kattan M, Baker D, Wright EC, Slavin R, Malveaux F. Results of the National Cooperative InnerCity Asthma Study (NCICAS) environmental intervention to reduce cockroach allergen exposure in inner-city homes. J Allergy Clin Immunol 1999;103:501-6.

27. Arbes SJ Jr, Sever M, Mehta J, Gore JC, Schal C, Vaughn B, Mitchell H, Zeldin DC. Abatement of cockroach allergens (Bla g 1 and Bla g 2) in low-income, urban housing: Month 12 continuation results. J Allergy Clin Immunol 2004;113: 109-14.

28. Pollart SM, Smith TF, Morris EC, Gelber LE, Platts-Mills TAE, Chapman MD. Environmental exposure to cockroach allergens: analysis with monoclonal antibody-based enzyme immunoassays. J Allergy Clin Immunol 1991;87:505-10

29. Schou C, Fernandez-Caldas E, Lockey RF, Løwenstein H. Environmental assay for cockroach allergens. J Allergy Clin Immunol 1991;87:828-34.

30. Dreborg S. Mite allergens. Collection, determination, expression of results and risk levels for sensitization and symptom induction. Allergy 1998;53(Suppl 48):88-91.

31. Fahlbusch B, Heinrich J, Groß I, Jäger L, Richter K, Wichmann HE. Allergens in house-dust samples in Germany: results of an East-West German comparison. Allergy 1999;54:1215-22.

32. Stelmach I, Jerzynska J, Stelmach W, Majak P, Chew G, Gorski P, Kuna P. Cockroach allergy and exposure to cockroach allergen in Polish children with asthma. Allergy 2002;57:701-5.

33. Kitch BT, Chew G, Burge HA, Muilenberg ML, Weiss ST, Platts-Mills TAE, O`Connor G, Gold DR. Socioeconomic predictors of high allergen levels in homes in the greater Boston area. Environ Health Perspect 2000;108:301-7.

34. Sarpong SB, Hamilton RG, Eggleston PA, Adkinson NF Socioeconomic status and race as risk factors for cockroach allergen exposure and sensitization in children with asthma. J Allergy Clin Immunol 1996;97:1393-401.

35. Wang C, El-Nour MM, Bennett GW. Survey of pest infestation, asthma, and allergy in low-income housing. J Community Health 2008;33:31-9.

36. Sarpong SB, Wood RA, Karrison T, Eggleston PA. Cockroach allergen (Bla g 1) in school dust. J Allergy Clin Immunol 1997;99:486-92.

37. Macan J, Plavec D, Kanceljak B, MIlković-Kraus S. Exposure levels and skin reactivity to german cockroach (Blatella germanica) in Croatia. Croat Med J 2003;44:756-60.

38. Prester Lj, Brčić Karačonji I, Macan J. Determination of mite allergens in house dust using the enzyme immunoassay. Arhiv Hig Rada Toksikol 2007;58:413-9.

39. De Blay F, Sanchez J, Hedelin G, Perez-Infante A, Vérot A, Chapman M, Pauli G. Dust and airborne exposure to allergens derived from cockroach (Blattella germanica) in low-cost public housing in Strasbourg (France). J Allergy Clin Immunol 1997;99:107-12.

40. Custovic A, Green R, Taggart SC, Smith A, Pickering CA, Chapman MD, Woodcock A. Domestic allergens in public places.II: Dog (Can f 1) and cockroach (Bla g 2) allergens in dust and mite, cat, dog and cockroach allergens in the air in public buildings. Clin Exp Allergy 1996;26:1246-52.

41. Lamiaa B, Mariam L, Ahmed A. Bacteriological analysis of Periplaneta americana L. (Dictyoptera; Blattidae) and Musca domestica L. (Diptera; Muscidae) in ten districts of Tangier, Morocco. Afr J Biotechol 2007;6:2038-42.

42. Pomés A, Chapman MD, Vailes LD, Blundell TL, Dhanara V. Cockroach allergen Bla g 2. Am J Respir Crit Care Med 2002;165:391-7.

43. Prester Lj, Macan J. Determination of Alt a I (Alternaria alternata) in poultry farms and a sawmill using ELISA. Med Mycol 2010;48:298-302.

44. Prester Lj, Macan J, Matković K, Vučemilo M. Determination of Aspergillus fumigatus allergen 1 in poultry farms using the enzyme immunoassay. Arh Hig Rada Toksikol 2010;61: $167-73$. 


\title{
Sažetak
}

\section{RAZINE ALERGENA Bla g 1 (BLATELLA GERMANICA) U KUĆNOJ PRAŠINI S PODRUČJA GRADA} ZAGREBA

\begin{abstract}
Alergija na žohare zdravstveni je problem u mnogim dijelovima svijeta. Prisutnost alergena žohara u kućanstvu važan je faktor rizika za nastanak astme u gradskoj sredini. Cilj ovoga rada bio je odrediti maseni udjel Bla g 1, glavnog alergena smeđeg žohara (Blatella germanica) u 30 uzoraka kućne prašine uzorkovanih u neselektivno izabranim kućanstvima sa šireg područja Zagreba. Uzorci prašine skupljeni su usisavanjem prašine s poda u dnevnom boravku na celulozne filtre. Nakon ekstrakcije, Bla g 1 je određen komercijalnim enzim-imunokemijskim testom. Maseni udjeli alergena Bla g 1 bili su mjerljivi u samo 4 od 30 kućanstava (13,3\%). Koncentracija Bla g $1>2 \mathrm{U} \mathrm{g}^{-1} \mathrm{koja}$ se povezuje s pojavom senzibilizacije u ljudi ustanovljena je u jednom od 30 kućanstava (3,3\%). Bla g 1 ELISA vrlo je osjetljiva metoda s granicom detekcije od $0.12 \mathrm{U} \mathrm{g}^{-1}$, a dobiveni su zadovoljavajući rezultati za analitičku nepreciznost i netočnost.

Rezultati ove pilot-studije pokazuju da je razina alergena Bla g 1 u kućnoj prašini s područja Zagreba vrlo niska, što je sukladno ranijim podatcima o niskoj učestalosti kožne reaktivnosti na smeđeg žohara u odrasloj populaciji iz istog područja. Zbog moguće razlike u izloženosti i senzibilizaciji stanovništva alergenima žohara ovisno o geografskom području, trebalo bi provesti daljnja ispitivanja.
\end{abstract}

KLJUČNE RIJEČI: alergeni unutarnjih prostora, alergija, ELISA, žohari

\section{CORRESPONDING AUTHOR:}

\section{Ljerka Prester}

Institute for Medical Research and Occupational Health

Ksaverska c. 2, 10000 Zagreb, Croatia

E-mail:prester@imi.hr 